\title{
Modelling the potential of rainwater harvesting in western Kenya using remote sensing and GIS techniques
}

\author{
Samuel M. Nthuni ${ }^{1,2}$, Tillmann Lübker ${ }^{1,3} \&$ Gertrud Schaab ${ }^{1, *}$ \\ ${ }^{1}$ Karlsruhe University of Applied Sciences, Faculty of Information Management and Media, \\ Moltkestrasse 30, D-76133 Karlsruhe, Germany \\ ${ }^{2}$ current affiliation: University of Nairobi, Department of Geospatial and Space Technology, Kenya \\ ${ }^{3}$ current affiliation: Landesvermessung und Geobasisinformation Brandenburg, Potsdam, Germany \\ * corresponding author, gertrud.schaab@hs-karlsruhe.de
}

DOI: http://dx.doi.org/10.4314/sajg.v3i3.3

\begin{abstract}
Water scarcity is among the many problems faced today by many countries in the world, especially African countries. The Kakamega area in western Kenya is known for plenty of rainfall (around $2000 \mathrm{~mm}$ annually), however, rainwater harvesting (RHW) from roofs is not yet a common practice in the region. In this study, we determined the potential of $R W H$ as an alternative or preferred source of safe water for domestic use. Spatial modelling techniques using amount of rainfall, census data and detailed information available from the classification of very high resolution QuickBird satellite imagery as input data were applied to implement various approaches. Four conceptual models were developed at three different levels of detail: the Kakamega-Nandi forests area $\left(3900 \mathrm{~km}^{2}\right)$, the QuickBird imagery covered area $\left(473 \mathrm{~km}^{2}\right.$ of farmland) and Buyangu village $\left(1.9 \mathrm{~km}^{2}\right)$. The four models were implemented in ArcGIS ModelBuilder and reveal the potential of such spatially explicit simulations to guide planners and to demonstrate the benefits of RWH to the local people. In the Kakamega-Nandi forests area, it rains enough to meet the annual water demand of 7300 l per person almost throughout the entire area.
\end{abstract}

\section{Introduction}

The Kakamega Forest area in western Kenya is known for plenty of rainfall. Here, forest cover impacts rainfall distribution at the regional level (cp. Sheil, 2014). Nevertheless, women and children walk long distances to collect water for domestic use. The estimated 225,000 people living within a $2 \mathrm{~km}$-buffer of the forest boundary depend on Kakamega Forest for their livelihood (Mitchell et al., 2009). The common local forest uses include not only collecting of water but also watering of cattle. These and other human activities have strongly contributed to the degradation of the forest (ibid.). However, only intact forest areas can provide such ecosystem services as water supply, climate regulation and $\mathrm{CO}_{2}$ fixing (NeFo, 2010). Therefore, the intended clear-cutting of more than 1450 hectares of forest in the South Nandi Forest, which is neighbouring Kakamega Forest, for a reservoir to provide water (GoK, 2011) would be counterproductive. 
People living in areas with forests make use of rainfall in numerous ways. In Eastern Africa (WRC, 2007), the availability of rainwater determines the spatial distribution and intensity of subsistence farming, i.e. of agricultural production. Therefore, a sustainable rainwater use is essential. This is becoming more critical as climate change impacts are now being experienced. Africa will be among those areas most greatly impacted (Boko et al., 2007). That is why stronger networking is called for, which can act as a means for managing the natural resources and thus long-term economic sustainability (IEMP, 2011). In this context, rainwater harvesting (RWH), a technology in practice for thousands of years (TWDB, 2005), is considered of high value and a sustainable alternative across the globe and also in areas like Kakamega. Predictions of RWH potential can be used to set up schemes for payment of ecosystem services (PES, e.g. Kaczan et al., 2013), which in turn can add a further valuable tool to forest management planning in the area (KWS \& KFS, 2012) by creating financial means for implementations on ground. RWH can take many different forms (e.g. Fayez \& Al-Shareef, 2009), however, this paper focuses on rainwater harvesting from roofs.

Estimating the potential of rainwater harvesting has been done for many years, especially for the semi-arid parts of the world. Many different methods, uses as well as spatial scales have been considered. At the smaller scale (i.e. for large geographic areas), surface runoff for irrigation of farmland is considered (Susilawati \& Tunggul, 2011), sometimes by differentiating between the varying water demand of crops (Andersson et al., 2009). Others aim at the potential of groundwater recharge in urban areas (Sekar \& Randhir, 2007). At the large scale (i.e. in greater detail), the amount of rainwater to be collected from building roofs for domestic use has been investigated (Vishwanath, 2001) along with avoiding flooding within cities (Hewa et al., 2007). In both cases, this is done by determining optimum tank or reservoir size needed to cope with drought periods while keeping costs at a minimum. Geospatial data and GIS are applied mainly to generate maps revealing areas of rainwater harvesting potential (Sekar \& Randhir, 2007; Mati et al., 2007) or to develop and operate decision support systems. These allow the determination of optimal locations for reservoirs and dams (Susilawati \& Tunggul, 2011; Weerasinghe et al., 2010). Also suitable sites for rainwater harvesting and hydrological impacts can be determined using socioeconomic data (Kahinda \& Taigbenu, 2011). The authors of this paper are only aware of one study in which buildings and thus roof area is treated in a spatially explicit way. In that study, 12 houses are modelled to find the optimum position for a shared water tank (Gupta \& Ralegoankar, 2006). In InVEST, a suite of software models that map and value goods and services from nature at the landscape scale or for whole countries (e.g. Daily et al., 2009), the potential of rainwater harvesting is not included. None of the cited studies have considered direct use of remote sensing imagery, although in applications for large areas, geodata originating from remote sensing applications may have been used. 


\section{Study area}

The study area (Figure 1) is $60 \mathrm{~km}$ by $65 \mathrm{~km}$ in size (34³7' ${ }^{\circ}$ 'E to $35^{\circ} 9^{\prime} 25^{\prime \prime} \mathrm{E}$ and $0^{\circ} 2^{\prime} 52^{\prime \prime} \mathrm{S}$ to $0^{\circ} 32^{\prime} 24^{\prime} \mathrm{N}$ ) and comprises the three major forest blocks Kakamega Forest, North Nandi Forest, and South Nandi Forest as well as several smaller forest fragments. The regional centre is Kakamega town and located about $40 \mathrm{~km}$ north of Kisumu and only $30 \mathrm{~km}$ north of the equator. The Kakamega Forest complex is situated at an elevation between $1420 \mathrm{~m}$ and $1765 \mathrm{~m}$ asl (Mitchell et $a l ., 2009)$. In the eastern part of the study area a $200 \mathrm{~m}$ to $300 \mathrm{~m}$ steep rise in terrain occurs that is referred to as the Nandi Escarpment, while the Nyando Escarpment in the southern part marks the beginning of the Kano Plains towards Kisumu (lowest point of study area: $1165 \mathrm{~m}$ asl). The two major rivers passing the area are Isiukhu in the north and Yala in the south, both contributing to the Lake Victoria basin.
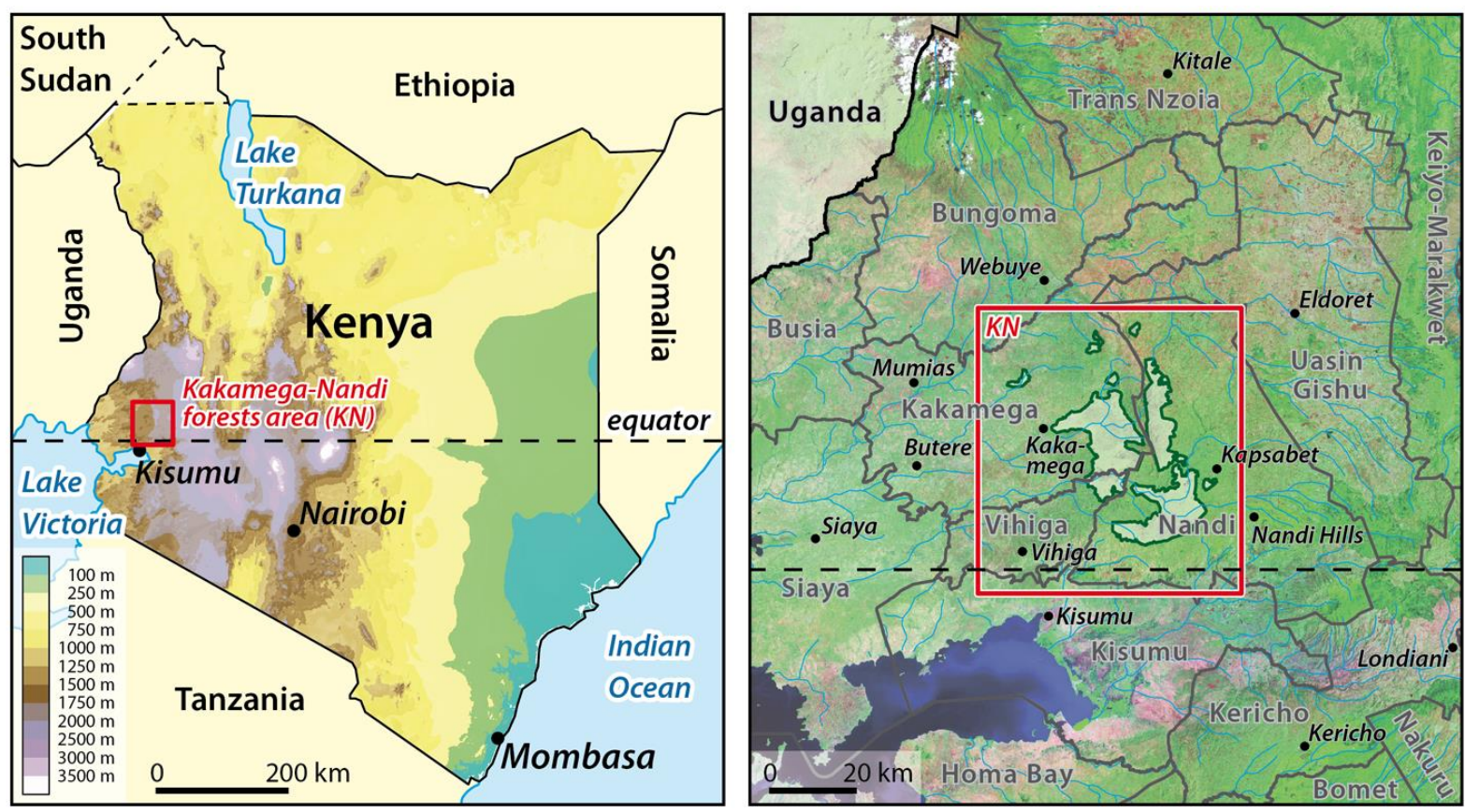

Figure 1. Location of the study area in western Kenya

The Kakamega-Nandi forests area is known to receive high amounts of precipitation with a mean annual sum of around $2000 \mathrm{~mm}$ (Blackett, 1994). Associated with the movement of the Intertropical Convergence Zone, two main rainfall seasons exist (Mugalavai et al., 2008). The long rains occur from mid-March to May while the short rains usually occur at some time between August and early December. Moreover, the regional climate is influenced by southwesterly winds from Lake Victoria and heavy rainfall every afternoon caused by the steep Nandi Escarpment east of Kakamega Forest (Flohn \& Fraedrich, 1966). Due to climate change, however, rainfall patterns are changing with extended periods of droughts occurring more frequently (cp. Mitchell et al., 2009).

The Kakamega area is among the most densely populated areas in Kenya (Kamugisha et al., 1997). In Kakamega District, population density was 575 inhabitants / km² in 1999 (GoK, 2001). The 
average number of people belonging to one household is estimated to be 4.9 for the study area (Lübker, 2013). The area faces a high poverty rate of 52\% (Kahuthu et al., 2005) and more than $80 \%$ of the households have no access to clean water (based on surveys in five divisions; Dose, 2007). The rural population heavily relies on subsistence farming, but farmland is scarce. A study conducted in the region revealed that two thirds of the households have less than 0.7 ha available (Kenea, 2008). People still collect water from rivers, streams, wells and boreholes. Despite the substantive precipitation, RWH from roofs is not yet a common practice in the region.

\section{Materials and methods}

\subsection{Data used}

For the Kakamega-Nandi forests area more than 300 geodatasets are available from the BIOTA East Africa project (Schaab \& Lung, 2010; see http://www.biota-africa.org/East_GISWeb1_ba.php? Page_ID=L800_04_03), among them very high resolution QuickBird satellite imagery (2.4 m for the multispectral bands, $0.60 \mathrm{~m}$ for the panchromatic band) with a unique classification result showing the distribution of individual houses. While the distribution of houses can serve as basis to model water demand in a spatially explicit way, climate data in combination with terrain information allows for the modelling of variation in rainwater availability over space and time.
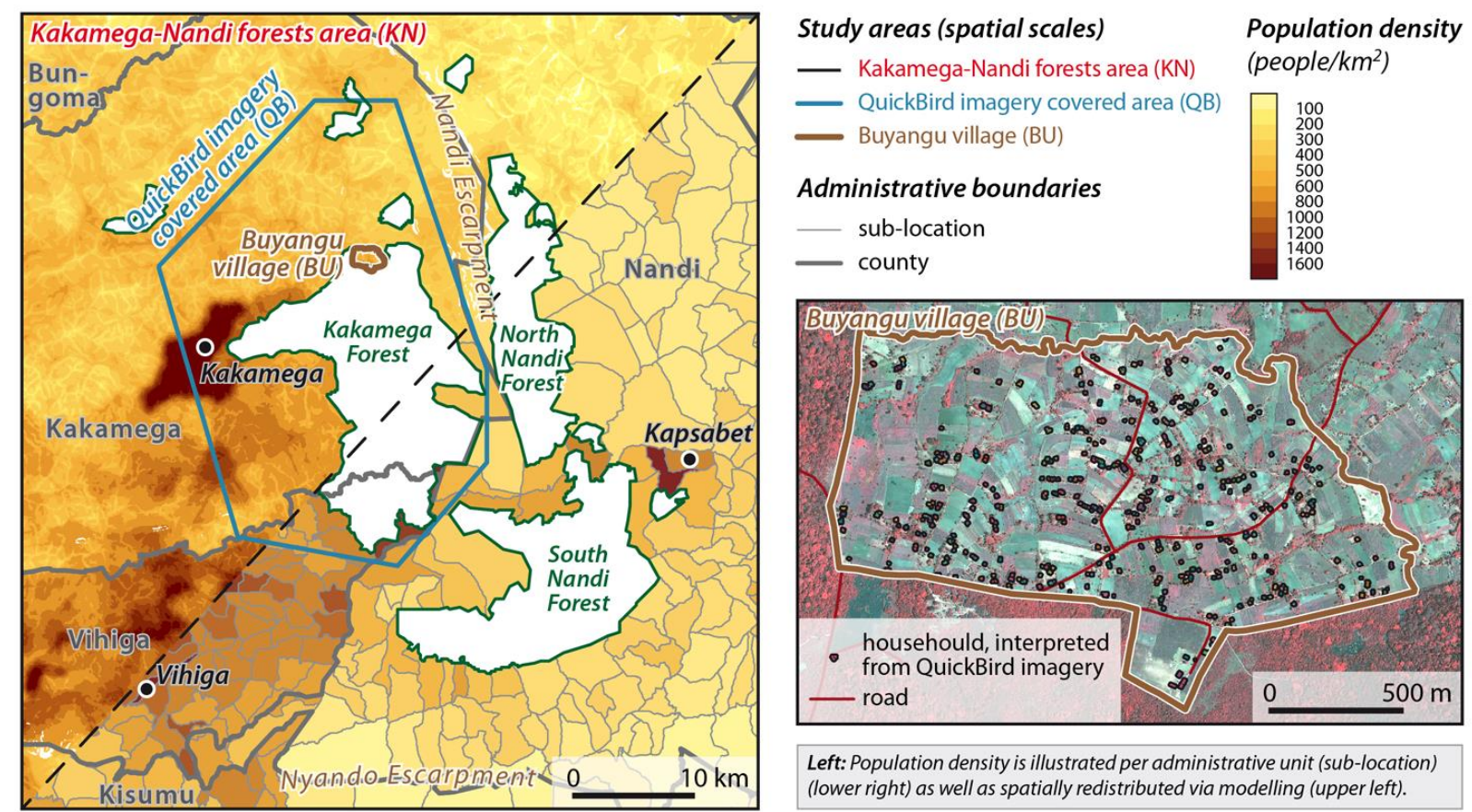

Figure 2. The three spatial scales focused on in the modelling of rainwater harvesting potential and their population distribution information used

Geodatasets available on population distribution (for scales and visual impressions of their level of detail see Figure 2) include census data per sub-location for the entire Kakamega-Nandi forests area, a common format used in administration and planning. QuickBird satellite image classification based on object-based image analysis (OBIA) (Schaab et al., 2011) resulted in a dataset revealing 
the distribution of individual houses for $473 \mathrm{~km}^{2}$ of farmland. Here $42 \%$ of all houses (including sheds) could be extracted, showing a total of 58,504 houses. The detected houses correspond to $72 \%$ of all tin-roofed houses (Lübker, 2013). Population redistribution of the census data for the Kakamega-Nandi forests area is based on correlations between the OBIA-derived houses and ancillary geodata (slope, proximity to roads, rivers, markets, and schools); additionally a masspreserving smoothing along administrative boundaries led to a more realistic population density mapping (Lung et al., 2013). For Buyangu village geodatasets on water collection points, rivers, as well as roads and footpaths are available from the BIOTA East Africa project, too.

Regarding climate, annual rainfall data for 19 stations are used, six are within the study area and 13 are as far as $53 \mathrm{~km}$ away. Climatological data from various sources (WMO, ILRI, BIOTA East Africa; for details see http://www.iaf.hs-karlsruhe.de/biota/online-geodata/metainfo/meta_kn_ precipStations_tl.pdf) and differing time periods (15 to 100 years within 1896 to 2005) have been gathered in order to allow for a spatial interpolation. Mean monthly rainfall data are available for Isecheno forest office for the period 1982 to 2002 (Mitchell et al., 2009). To represent the terrain, a Digital Elevation Model (DEM) of suitable $30 \mathrm{~m}$ resolution is available, generated from contour lines digitized from 1:50,000 scale topographic map sheets (Herz, 2004).

\subsection{Methods}

Modelling rainwater harvesting potential takes into consideration the total amount of rainwater received by a catchment surface over a period of time. However, not all of the rain that falls on the roof surface is collected. The rainwater use balance considers both rainwater harvesting potential and water demand (TWDB, 2005), this is also a prerequisite when determining a suitable storage tank volume for a specified area of roof. This in turn may require accounting for the initial amount of water already in the tank (Roebuck, 2007). Here, rainwater demand refers to all the domestic uses of water per individual or household in a given period of time. As the storage tank accounts for the highest cost for a rooftop rainwater harvesting system (Liaw \& Tsai, 2004), it is important to install the correctly sized tank for optimum rainwater harvesting (Kahinda et al., 2007). Rainfall is not constant throughout the year and therefore, adequate capacity is required for the constant use of rainwater even during dry periods. In addition, the amount of time saved and the economic benefit of rainwater harvesting can be accounted for. Rosen \& Vincent (1999) explain that the burden of collecting water from distant sources can be viewed in terms of time spent, the physical effort required and potential negative health effects. Rainwater harvesting suitability modelling considers the geographic location of the area, and thus the temporal and spatial variability of the rainfall (Kahinda et al., 2008).

\subsubsection{Population and rainfall distribution}

To have suitable data on population distribution available at all three spatial scales of the study, a visual interpretation of QuickBird imagery (using band combination R/G/B) was performed. For Buyangu village at the northern edge of Kakamega Forest (see Figure 2) every house and 
homesteads was manually digitized in ArcGIS. This process included not only the larger tin-roofed homes (cp. OBIA results), but all other buildings forming a farm and including grass-thatched houses and small sheds. The process also allowed for the grouping of houses to farms and thus to households.

For most of the 19 climatic stations only annual climate data were available. The mean monthly values of rainfall known for Isecheno forest office are used as a reference (Figure 4B). Mean monthly precipitation values are used to simulate relative changes in seasonal rainfall patterns. To create a realistic rainfall distribution throughout the Kakamega-Nandi forests area, spatial interpolation using a polynomial function was employed rather than a simpler inverse distance weighting interpolation. Here, the mean annual precipitation at 16 stations (only using those of relevance regarding location and elevation) and the DEM of $30 \mathrm{~m}$ resolution were considered. This yielded a highly significant correlation, $\mathrm{R}^{2}=0.94$ (Equation 1).

$$
\begin{aligned}
& y=1000+\left(1.86 \times 10^{-9}\right) x^{4}-\left(1.06 \times 10^{-5}\right) x^{3}+0.019 x^{2}-10.586 x \\
& y \text { represents rainfall amount in } \mathrm{mm} / \text { year, } \mathrm{x} \text { represents elevation in metres. }
\end{aligned}
$$

\subsubsection{Conceptual phase}

Based on methods described in the literature, upon available data at three different spatial scales (Kakamega-Nandi forests area, QuickBird imagery covered area, and Buyangu village), and upon knowledge of the area, four models for predicting RWH potential were generated (Nthuni, 2010). Table 1 provides an overview of their input, their anticipated output and the model intentions.

\begin{tabular}{|c|c|c|c|c|}
\hline & Model I & Model II & Model III & Model IV \\
\hline $\begin{array}{l}\text { Spatial scale } \\
\text { (level of detail) }\end{array}$ & $\begin{array}{l}\text { Kakamega-Nandi } \\
\text { forests area }(\mathrm{KN}, \\
\text { sub-locations })\end{array}$ & $\begin{array}{l}\text { Kakamega-Nandi } \\
\text { forests area }(\mathrm{KN}, \\
30 \mathrm{~m} \text { grid cells })\end{array}$ & $\begin{array}{l}\text { QuickBird imagery } \\
\text { covered area (QB) }\end{array}$ & Buyangu village (BU) \\
\hline $\begin{array}{l}\text { Size of area } \\
\text { covered }\end{array}$ & $3900 \mathrm{~km}^{2}$ & $3900 \mathrm{~km}^{2}$ & $473 \mathrm{~km}^{2}$ of farmland & $1.9 \mathrm{~km}^{2}$ \\
\hline Input & $\begin{array}{l}\text { - Rainfall data } \\
\text { - DEM } \\
\text { - Demographic data } \\
\text { - Administrative } \\
\text { units }\end{array}$ & $\begin{array}{l}\text { - Rainfall data } \\
\text { - DEM } \\
\text { - Demographic data } \\
\text { - Population density } \\
\text { per grid cell }\end{array}$ & $\begin{array}{l}\text { - Rainfall data } \\
\text { - DEM } \\
\text { - Demographic data } \\
\text { - Administrative } \\
\text { units } \\
\text { - OBIA houses }\end{array}$ & $\begin{array}{l}\text { - Rainfall (1 station) } \\
\text { - DEM } \\
\text { - All houses } \\
\text { - Water collection } \\
\text { points } \\
\text { - Topographic features } \\
\text { (rivers, roads, paths) }\end{array}$ \\
\hline Output & $\begin{array}{l}\text { - Graph: RW use } \\
\text { balance per month } \\
\text { (KN) } \\
\text { - Map: annual } \\
\text { RWH potential \& } \\
\text { RW use balance } \\
\text { per sub-location }\end{array}$ & $\begin{array}{l}\text { - Map: annual RWH } \\
\text { potential \& RW } \\
\text { use balance per } \\
\text { grid cell }\end{array}$ & $\begin{array}{l}\text { - Optimum tank size } \\
\text { (QB) } \\
\text { - Graph: RW use } \\
\text { balance per month/ } \\
\text { hh }(\mathrm{QB}) \text {, } \\
\text { - Table: RW endow- } \\
\text { ment \& RWH per } \\
\text { month/hh (QB) }\end{array}$ & $\begin{array}{l}\text { - Graph: RWH capa- } \\
\text { city \& W demand \& } \\
\text { RW use balance (BU) } \\
\text { - RWH investment vs. } \\
\text { value of time spent } \\
\text { collecting W per } \\
\text { month/hh } \\
\text { - Map: interim results }\end{array}$ \\
\hline
\end{tabular}

Table 1 . The four conceptualized models to predict RWH potential 


\begin{tabular}{lllll}
\hline Model purpose & $\begin{array}{l}\text { Which sub-location } \\
\text { is meeting the water } \\
\text { demand? }\end{array}$ & $\begin{array}{l}\text { Revealing patterns } \\
\text { within sub-locations } \\
\text { (due to considering } \\
\text { variation in rainfall } \\
\text { and population) }\end{array}$ & $\begin{array}{l}\text { In order to determine } \\
\text { optimum tank size } \\
\text { (monthly overflow?) }\end{array}$ & $\begin{array}{l}\text { To demonstrate the } \\
\text { monetary value of } \\
\text { RWH (for a given tank } \\
\text { size) to the local people }\end{array}$ \\
Target groups & $\begin{array}{l}\text { For organizations } \\
\text { promoting RWH }\end{array}$ & $\begin{array}{l}\text { For organizations } \\
\text { promoting RWH }\end{array}$ & $\begin{array}{l}\text { For NGOs helping to } \\
\text { finance RWH }\end{array}$ & $\begin{array}{l}\text { For NGO/CBOs } \\
\text { marketing RWH }\end{array}$ \\
\hline
\end{tabular}

The models require a number of constants and parameters. These were obtained either from literature research, derived from geodata processing (analysis of QuickBird imagery), based on local knowledge, or assumed:

- $\quad$ runoff coefficient (RC): 0.85 (Oduor \& Gadain, 2007)

- standard roof catchment area (SRCA): $46 \mathrm{~m}^{2}$ (determined by QuickBird image analysis)

- ratio of tin-roofed houses to all houses (RTA): $1: 1.39$ (0.72) (determined by QuickBird image analysis)

- tank volume (TV): 1000 litres (assumed; variable model parameter)

- cost of tank (CT): Ksh. 3700 (assumed; variable model parameter)

- cost of delivery and conveyance system (CDC): Ksh. 2000 (assumed; variable model parameter)

- $\quad$ average walking speed for a woman (S): $4 \mathrm{~km} / \mathrm{h}$ (Massaad et al., 2007)

- $\quad$ water demand per person per day (WD): 20 litres (UNDP, 2006).

- number of houses per household (h/hh): 1.77/hh (determined by QuickBird image analysis and demographic data)

- amount of water collected per person per trip (W): 20 litres (local knowledge)

- value of time, per person (Vt): $10 \mathrm{Ksh} . / \mathrm{h}$ (assumed)

\subsubsection{Implementation of models}

The models were developed with the help of the ModelBuilder in ArcGIS (Nthuni, 2010).

\section{Implementation of Model I: Kakamega-Nandi forests area at sub-location level}

This model determines the mean monthly rainfall distribution per sub-location by averaging the interpolated grid cell values falling within each sub-location (Figure 3). Based on the demographic data (households) and some parameters determined from QuickBird image analysis (see Figure 3 in combination with section 3.2.2), the total tin-roof catchment area is derived for each sub-location. This allows computing monthly rainfall endowment and the monthly RWH potential per administrative unit. Population figures and the daily water demand per person lead to the monthly water demand per sub-location. RWH potential less the water demand calculates the monthly rainwater use balance per sub-location. 


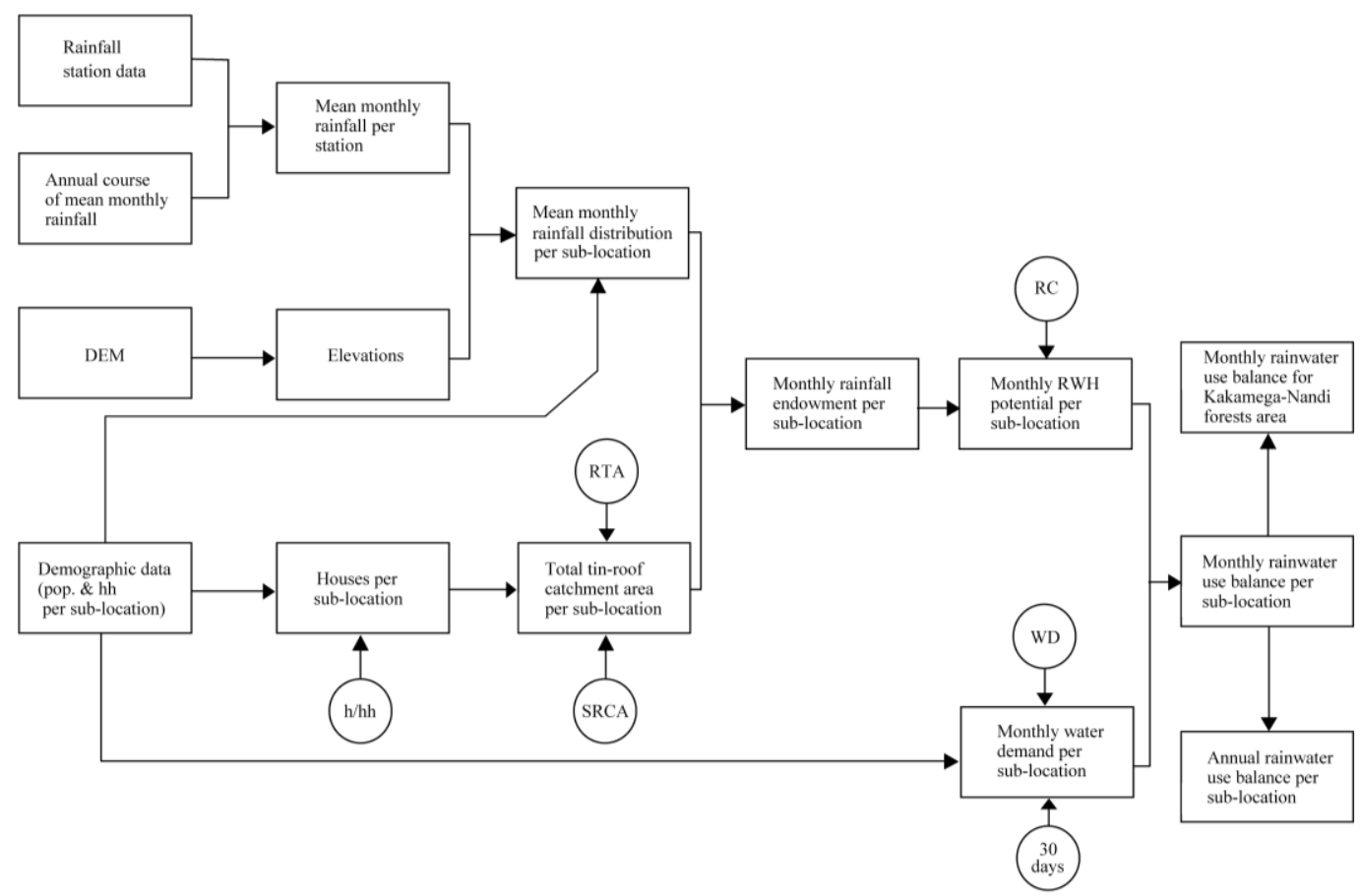

Figure 3. Conceptual modelling flowchart for Model I predicting RWH potential in the KakamegaNandi forests area at sub-location level (for abbreviations see section 3.2.2)

\section{Implementation of Model II: Kakamega-Nandi forests area at grid cell level}

This model runs for the same geographic area as Model I but the level of detail is $30 \mathrm{~m}$ grid cells. The major difference to Model I is that population is considered via the redistributed, gridded population density dataset. Therefore no aggregation of the rainfall and the RWH potential per sublocation is acquired. Instead all interim results as well as the final RWH potential are determined for each grid cell.

\section{Implementation of Model III: area covered by QuickBird imagery}

This model considers the roof catchment surface as determined via the analysis of QuickBird imagery. At this scale the volume of the storage tank plays an important role. It is assumed that as the model begins, monthly rainwater use balance is zero, i.e. the tank is empty. Further, the optimum tank size should be the one at which the monthly demand is satisfied and rainwater use balance at the end of each month is at least equal to the water demand for one month but not more than that of two months per household. Lastly, for health reasons water can be stored for a maximum of two months, as people in the area use no other water purification means than filters. Therefore, if the storage tank is not filled for two consecutive months, the tank should be emptied leaving the rainwater use balance as zero for the following month. Final output for this model is the monthly rainwater use balance for 12 months with respect to an optimally sized and used tank. 


\section{Implementation of Model IV: Buyangu village}

For Buyangu village only rainfall data of one nearby station is used because of negligible orographic effects. The total roof catchment area per household is computed from the visually interpreted and digitized houses. A cost surface is generated considering slope (derived from the DEM), rivers (acting as barriers), roads and footpaths (no resistance), homesteads, and farmland (i.e. the remaining area). In a next step the accumulated 'costs' of moving the water from specific points to any household (the more labourious direction carrying the load) is computed. Finally the least cost effective paths for each household are determined, which allows for the calculation of the monthly time spent to collect the required water. Comparison of the costs for the equipment needed for RWH with the monetary value of time spent for collecting water (i.e. savings in theory per household) reveals how long it will take until the investment will have paid for itself.

\section{Results and discussion}

\subsection{Interpolated rainfall}

Figure 4 combines the correlation between rainfall and elevation, the resulting spatial interpolation of annual precipitation based on 16 stations, and the mean monthly rainfall experienced in the area. The relationship (Figure 4A) describes an increase in precipitation with elevation up to $1600 \mathrm{~m}$ asl, beyond which the relationship is inverted. A sharp difference in rainfall for the windward (western) and leeward (eastern) side of the Nandi Escarpment (of $1680 \mathrm{~m}$ mean elevation) is revealed, which makes the Nandi Escarpment indirectly visible in the spatial interpolation (Figure 4C). Because of this, simpler approaches such as using a readily available
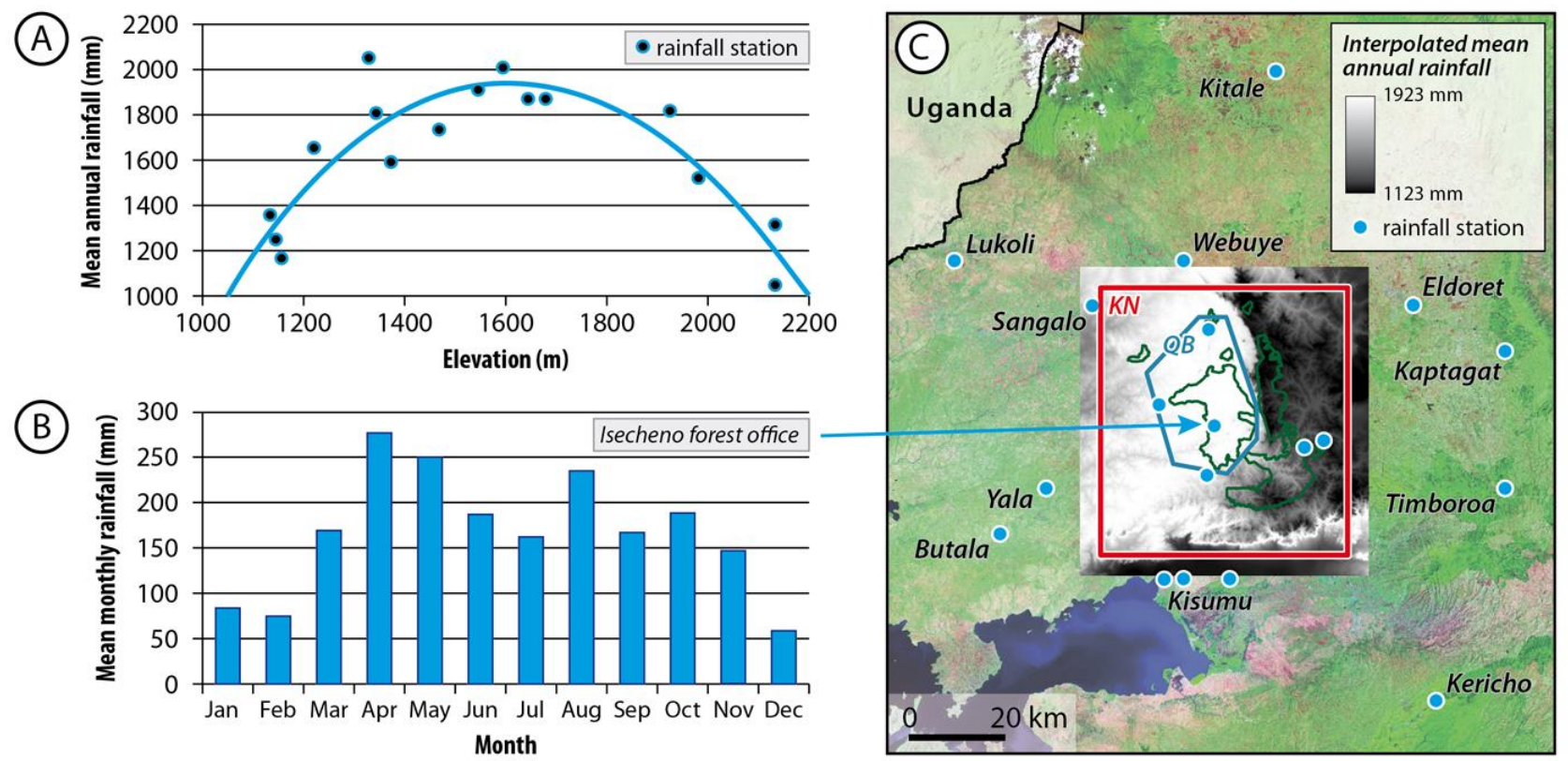

(B)

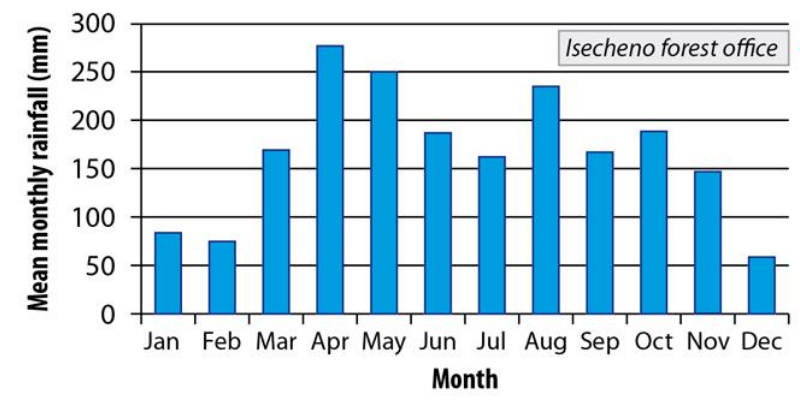

Figure 4. Spatio-temporal interpolation of rainfall for Kakamega-Nandi forests area: A) correlation with elevation (see Equation 1), B) seasonal rainfall pattern (Isecheno forest office, 1982 - 2002), C) interpolated annual rainfall distribution with rainfall stations considered 
continent-wide mean annual rainfall geodataset (e.g. Mati et al., 2007) for estimating the RWH potential would not be sufficient to reflect the pattern in rainfall known for the area. The reasoning for excluding the values of three stations (Kitale, Kaptagat, and Timboroa), is that all are found more than $50 \mathrm{~km}$ east or north of the Kakamega-Nandi forests area and they are not within the relevant elevational range.

\subsection{Annual RWH potential versus annual water demand (Models I and II)}

Figure 5A shows the distribution of RWH harvesting potential in the Kakamega-Nandi forests area at sub-location level. The pattern reflects those of population density (Figure 2) and rainfall in the area (Figure 4C), although variation in people per household also matters. Population density is high around Kakamega Forest and highest in the southwestern part of the area, where it coincides with high annual rainfall. On the escarpment (east of North Nandi and south of South Nandi forests) population density is much lower and rainfall is less. A surprising result is the high RWH potential in the south of the Nyando Escarpment, along the southern edge of the study area where both population density and rainfall amounts are low. The assumption of a fixed ratio of houses per household and the resulting average total tin-roof catchment area per sub-location has its drawbacks as it does not account for differences between urban versus rural settings. For the area around Kakamega town an overestimation of RWH potential is likely as compared to the more realistic results for rural settings. Only three sub-locations, placed at the southern and eastern edge of the study area and being marked in red in Figure 5A, do not have enough RWH potential to meet the water demand of their inhabitants. Daily water demand per person is 20 litres or 7,300 litres per year. In the sub-location section of Samoei at the eastern edge of the study area, the monthly water demand was determined as 332 kilolitres for 553 people. Figure 5B shows that only the RWH potential for April, May and August is enough to meet the monthly water demand in this sublocation. Here the monthly course in RWH potential is directly linked to the course of monthly rainfall (Figure 4B). While modelling predicts a high potential for RWH almost throughout the Kakamega-Nandi forests area, the three sub-locations not meeting the demand are those where higher population densities meet lowest annual rainfall and thus point to a possible future situation for an increasing number of sub-locations due to increasing populations and droughts.

By providing results per sub-location, Model I results clearly demonstrate its usefulness at the planning level, while Model II results (although not shown) are revealing variations of RWH potential within the sub-locations, as neither rainfall nor population distribution is distributed homogeneously across administrative units. This refined approach is based on a realistic distribution of people in the landscape depending on environmental as well as infrastructure conditions (Lung et al., 2013; see Figure 2) and grid-cell wise interpolated rainfall distribution (Figure 4C) and thus allows for more targeted attention by the RWH implementers. 

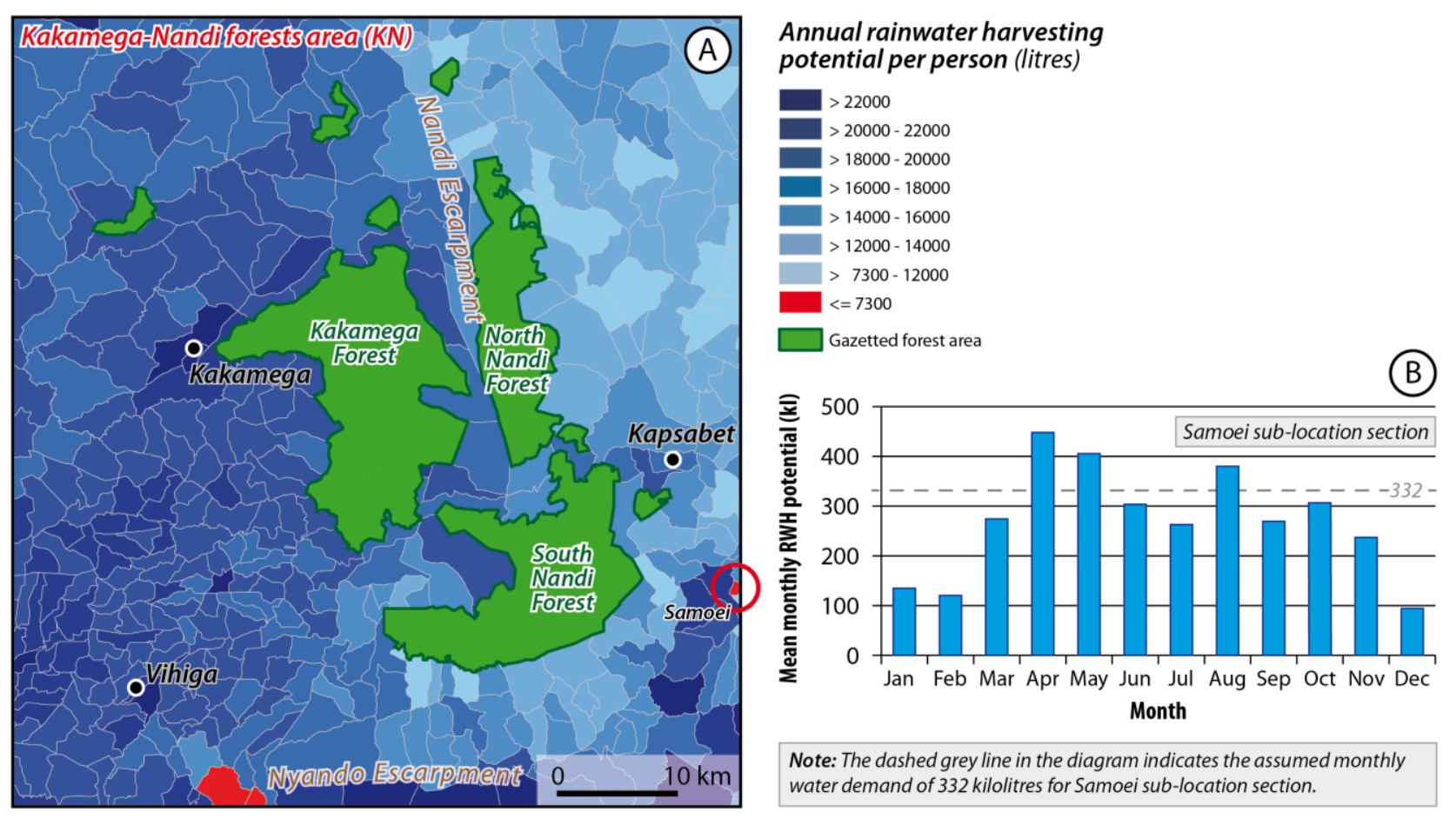

Figure 5. A) Distribution of annual RWH potential per person in the Kakamega-Nandi forests area at sub-location level, B) monthly RWH potential for a sample sub-location (Model I)

\subsection{Determining an optimum tank size (Model III)}

Figure 5B does not consider the use of a tank to store rainwater for use in drier months. But a storage tank is considered an integral part of the rooftop RWH technique, as it will help to bridge times of natural water shortage (cp. Manoj \& Mathew, 2008). This is demonstrated in Figure 6, which shows monthly RWH potential and monthly rainwater capacity per house when using a 1000 1 storage tank. The values refer to means calculated for the QuickBird imagery covered area (Model III). The monthly rainwater capacity considers the daily water demand, and thus constitutes the monthly rainwater harvested (considering the tank size) plus the rainwater balance brought forward from the previous month. It is important to note that modelling per month started with April, the month of highest rainfall. For this situation, with an average population per 'OBIA house' of 3.73 and its monthly water demand of 2,238 litres, the tank size of 10001 was determined by the model to be the optimum size. With this tank size, a household is able to meet its water demand throughout the whole year. The volume of the tank covers more than enough for the drier spells of June/July and September in between the rainy period from March to November, but is optimum for the dry period from December to February. However, this may be influenced by the selected start month being the one with the highest rainfall. Hewa et al. (2007) conclude that rainfall seasonality in Colombo has a major influence on tank size selection. Within the smaller area covered by Model III variations throughout the landscape are expected to be less as compared to the wider extent as treated in Model I (cp. Figure 4C with Figure 2). 


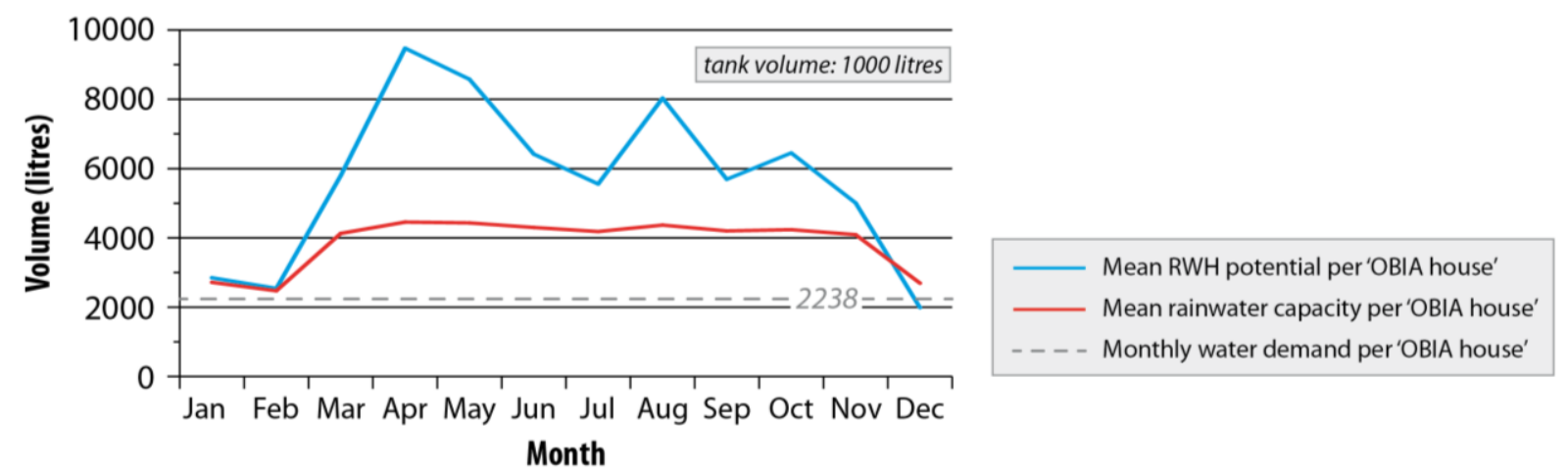

Figure 6. Relationship between mean monthly RWH potential and the mean amount of rainwater harvested (Model III, per 'OBIA house')

\subsection{Revealing time spent on water collection (Model IV)}

In Model IV least cost distance paths and the average walking speed are used to determine how long it takes women and children from each household to walk to the water collection point and back. Figure 7 shows the number of hours each household spends on fetching water to meet their monthly water demand. Most of the households spend less than 60 hours per month on water collection. This is equivalent to two hours per day per household. However there are also households that spend more than 60 hours per month on water collection. This time could be put in other socio-economic activities. The model did not consider circumstances where people might spend more time in case there are many people waiting to fetch water. In such cases, the time spent collecting water will be even more than what the model estimated. The selected result clearly demonstrates the potential of Model IV, where the varying conditions per household can be treated individually (cp. Gupta \& Ralegoankar, 2006). We are aware, however, that although every single roof of Buyangu village (as digitized from satellite imagery of 2005) was considered, household member numbers were not available.

With the increase in details from Model I to Model IV, the possibilities for output increase and can be used to create awareness and sensitize for longterm RWH benefits among the local people, as called for by Vishwanath (2001). With Model IV (Table 1) the period of return on expenditures for RWH equipment can be determined per household in Buyangu village. The one-time investment is assumed to total to Ksh. 5700 for a 10001 tank and the delivery and conveyance system (see section 3.2.2). For a representative household (circled in Figure 7) with a tin-roof catchment of 53 $\mathrm{m}^{2}$, a monthly water demand of 3,030 litres (using 5.05 people per household, the average in Buyangu) and a least cost distance to and from the nearest water point of $384 \mathrm{~m}$, it will take 20 months for the investment to pay itself off. The 29 hours per month, which are normally spent by the household members on fetching water to meet the daily domestic water demand, are here assumed to be spent on income generating activities creating a Ksh. 290 as the monthly return on investment. This additional time plus the benefit from a good water quality will last for as long as the RWH system functions. 


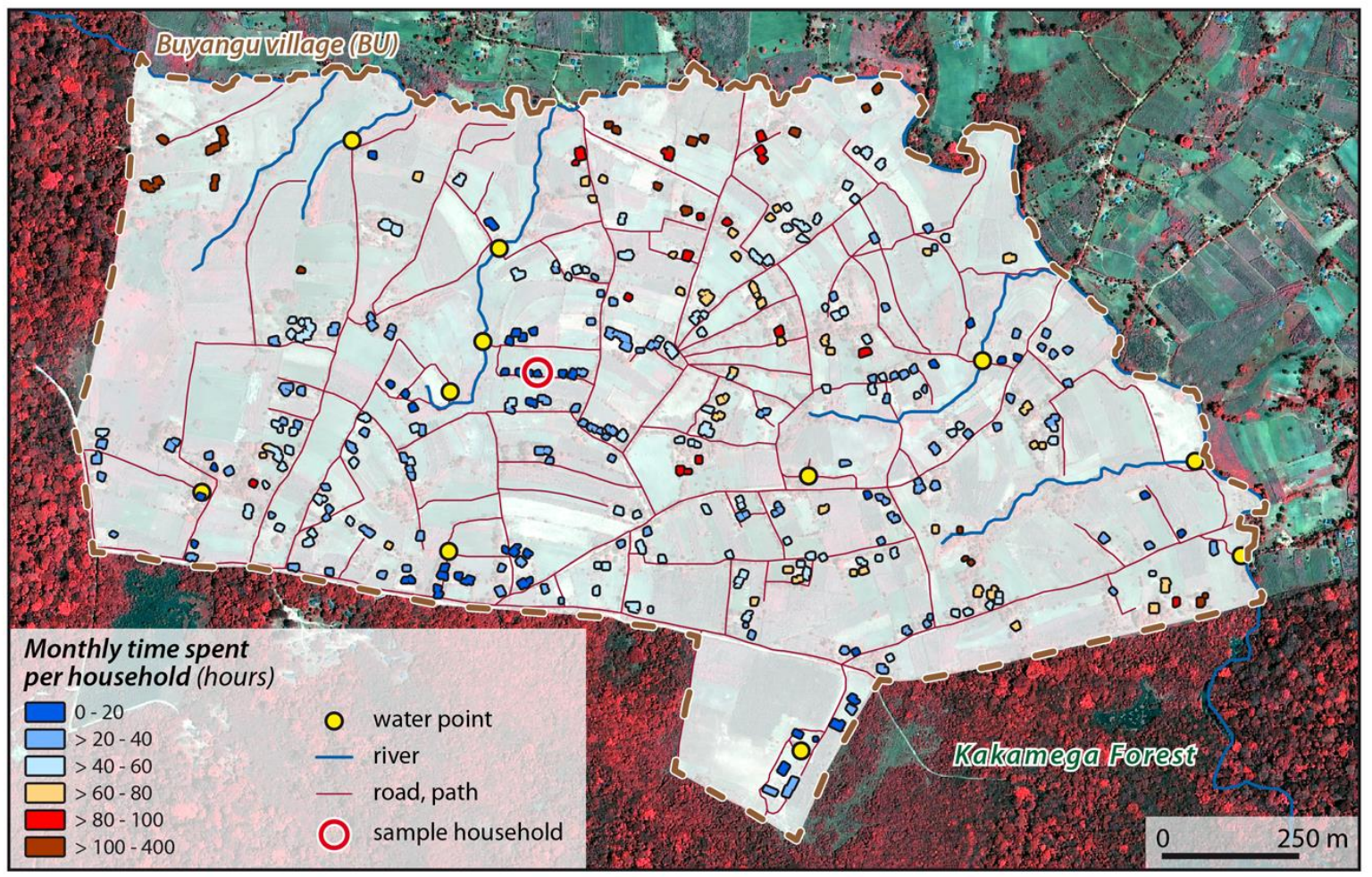

Figure 7. Time spent on water collection from the 'closest' water point per household and month (Model IV, Buyangu village)

\section{Conclusion}

The results of the models revealed that there is high rainwater harvesting potential in Kakamega area and if optimally harvested, the domestic water demand is met almost throughout. Not considered in the models are other rainwater uses such as tree nurseries, small-scale irrigation and livestock consumption, which could also benefit from RWH as can be interpreted from our results of modelling domestic uses. If the household water demands are met, women will have additional time to engage themselves in other income generating activities and children to concentrate on school work, and a secure source for good hygiene is provided for the whole household. However, this is subject to the availability of income generating activities in the area and that the climatic conditions do not change for the worse. Also, we are aware that water collection by women is a tradition with a high social and communicative value. In summary, with the prevailing climatic conditions, RWH is a viable and affordable technology for the Kakamega area. The results of four models employed here address different target groups which all promote RWH. It is through them and the inhabitants of the area that the service offered by rainfall can be harvested.

So far the models are prototypes with rudimentary graphical user interfaces and realized on the ArcGIS platform. Easy-to-use and well-documented stand-alone models would surely enhance their usability by the target groups addressed. Via an exchange with RWH experts the desired features of each model (see plans for output as listed in Table 1) should be determined. A professional programming in a higher language and making use of open source, free GIS software might be 
beneficial. Before finally applying the tools, in-depth model evaluation is still required (e.g. tuning of the cost surface in Model IV). But then, NGOs can be addressed which are keen in letting RWH become a common technology in Kakamega area. This would require awareness creation and micro-financing options. On the condition that similar geodata are available, the models could also be applied in any other area where RWH from rooftops is an option. Here, remote sensing is a valuable source to generate more realistic data on the actual distribution of the population.

\section{References}

Andersson, JCM, Zehnder, AJB, Jewitt, GPW \& Yang, H 2009, 'Water availability, demand and reliability of in situ water harvesting in smallholder rain-fed agriculture in the Thukela River basin, South Africa', Hydrology and Earth System Sciences, vol. 13, pp. 2329-2347.

Blackett, H 1994, Forest Inventory Report No. 3: Kakamega, Forest Department / KIFCON, Nairobi, Kenya.

Boko, M, Niang, I, Nyong, A, Vogel, C, Githeko, A, Medany, M, Osman-Elasha, B, Tabo, R \& Yanda, P 2007, Africa. Climate change 2007: Impacts, adaptation and vulnerability. Contribution of working group II to the fourth assessment report of the intergovernmental panel on climate change (ed. by ML Parry, OF Canziani, JP Palautikof, PJ van der Linden \& CE Hanson), Cambridge, pp. 433-467, viewed on 26 November 2013, <http://www.ipcc.ch/pdf/assessment-report/ar4/wg2/ar4-wg2-chapter9.pdf>.

Daily, GC, Polasky, S, Goldstein, J, Kareiva, PM, Mooney, HA, Pejchar, L, Ricketts, TH, Salzman, J \& Shallenberger, R 2009, 'Ecosystem services in decision making: time to deliver', Frontiers in Ecology and the Environment, vol. 7, no. 1, pp. 21-28.

Dose, H 2007, Securing household income among small-scale farmers in Kakamega District: Possibilities and limitations of diversification. GIGA Working Papers No. 41, German Institute of Global and Area Studies (GIGA), Hamburg, Germany.

Fayez, AA \& Al-Shareef, AW 2009, 'Roof rainwater harvesting systems for household water supply in Jordan', Desalination, no. 243, pp. 195-207.

Flohn, H \& Fraedrich, K. 1966, 'Tagesperiodische Zirkulation und Niederschlagsverteilung am Victoria-See (Ostafrika)', Meteorologische Rundschau, vol. 19, pp. 157-165.

GoK (Government of Kenya) 2011, Nandi forest multipurpose dam development project on Yala river, Environmental Impact Assessment Executive Summary, Ministry of Regional Development Authorities in assoc. with TYPSA (Spain) and ama (Kenya).

GoK (Government of Kenya) 2001, 1999 population and housing census. Counting our people for development, vols. I and II, Ministry of Finance and Planning, Central Bureau of Statistics, Nairobi, Kenya.

Gupta, R \& Ralegoankar, RV 2006, ‘Design and development of a rainwater-harvesting system’, International Conference on "From Invention and Development to Product, From Research Institutes to the Water Industry”, Sede Boqer (Israel), 28-30 November 2006, pp. 61-66.

Herz, O 2004, 'Georeferenzierung und Mosaikierung von historischen Luftbildern für den Kakamega Forest und assoziierte Waldgebiete (Westkenia) sowie erste visuelle Auswertung bzgl. Landbedeckungs- 
änderungen', Unpublished Bachelor's Thesis, Faculty of Geomatics, Karlsruhe University of Applied Sciences, Germany.

Hewa, G, Pezzaniti, D, Beecham, S \& Gupta, K 2007, 'Selecting an appropriate size for domestic rainwater tanks in Colombo', 32nd WEDC International Conference "Sustainable Development of Water Resources, Water Supply and Environmental Sanitation", Colombo (Sri Lanka), 13-17 November 2006, pp. 445-450 (ed. by J Fisher).

IEMP (International Ecosystem Management Partnerships) 2011, Putting Ecosystem Management in the Vision of Africa's Development, UNEP Policy Brief 7-2011, viewed 26 November 2013, $<$ http://www.unep.org/ecosystemmanagement/Portals/7/Putting\%20Ecosystem\%20Management\%20in\% 20the\%20Vision\%20of\%20Africa\%E2\%80\%99s\%20Development-Policy\%20Paper.pdf>.

Kaczan, D, Swallow, BM, Adamowicz, WL 2013, 'Designing a payments for ecosystem services (PES) program to reduce deforestation in Tanzania: An assessment of payment approaches', Ecological Economics, vol. 95, pp. 20-30.

Kahinda, JM., Akpofure, ET \& Boroto, JR 2007, 'Domestic rainwater harvesting to improve water supply in rural South Africa', Physics and Chemistry of the Earth, vol. 32, pp. 1050-1057.

Kahinda, JM, Lillie, ESB, Taigbenu, AE, Taute, M \& Boroto, RJ 2008, 'Developing suitability maps for rainwater harvesting in South Africa', Journal of Physics and Chemistry of the Earth, vol. 33, pp. 788799.

Kahinda, JM \& Taigbenu, AE 2011, 'Rainwater harvesting in South Africa: Challenges and opportunities', Physics and Chemistry of the Earth, vol. 36, pp. 968-976.

Kahuthu, R, Muchoki, C \& Nyaga, C 2005, Kakamega District strategic plan 2005 - 2010 for implementation of the National Population Policy for Sustainable Development. National Coordinating Agency for Population and Development (NCAPD), Nairobi, Kenya.

Kamugisha, JR, Ogutu, ZA \& Stahl, M 1997, Parks and people: conservation \& livelihoods at the crossroads. Four case studies, Technical Report 17, Regional Soil Conservation Unit (RSCU) / Swedish International Development Cooperation Agency (SIDA), Nairobi, Kenya.

Kenea, W 2008, Rural livelihood, land management and biodiversity: Community participation for biodiversity conservation, PhD thesis, Faculty of Spatial Planning, TU Dortmund University, Germany (urn:nbn:de:hbz:290-2003/26623-1).

KWS (Kenya Wildlife Service) \& KFS (Kenya Forest Service) (eds.) 2012, Kakamega forest ecosystem management plan 2012-2022, Nairobi Kakamega, Kenya.

Liaw, CH \& Tsai, YL 2004, 'Optimum storage volume of rooftop rain water harvesting systems for domestic use', American Water Resources Association, vol. 40, no. 4, pp. 901-912.

Lübker, T 2013, 'Object-based remote sensing for modelling scenarios of rural livelihoods in the highly structured farmland surrounding Kakamega Forest, western Kenya, PhD Thesis (defended, but not yet published), Institute for Cartography, Technical University of Dresden, Germany.

Lung, T, Lübker, T, Ngochoch, JK \& Schaab, G 2013, 'Human population distribution modelling at regional level using very high resolution satellite imagery’, Applied Geography, vol. 41, pp. 36-45. 
Manoj, PS \& Mathew, AC 2008, 'Rejuvenation of water bodies by adopting rainwater harvesting and groundwater recharging practices in catchment area - a case study', The 12th World Lake Conference (Taal 2007), Jaipur (India), 28 October - 2 November 2007, pp. 766-776 (ed. by M Sengupta \& R Dalwani).

Massaad, F, Lejeune, TM \& Detrembleur, C 2007, 'The up and down bobbing of human walking: A compromise between muscle work and efficiency', Physiology, vol. 582, pp. 789-799.

Mati, B, De Bock, T, Malesu, M, Khaka, E, Oduor, A, Nyabenge, M \& Oduor, V 2007, Mapping the potential of rainwater harvesting technologies in Africa: A GIS overview and atlas of development domains for the continent and ten selected countries, Technical Manual No. 6, World Agroforestry Centre (ICRAF), Nairobi, Kenya, viewed 28 August 2010,

<http://worldagroforestrycentre.net/downloads/publications/PDFs/MN15297.PDF>.

Mitchell, N, Schaab, G \& Wägele, JW (eds.) 2009, Kakamega Forest ecosystem: An introduction to the natural history and the human context. Karlsruher Geowissenschaftliche Schriften (KGS), Series A, vol. 17 (ed. by G Schaab).

Mugalavai, E, Kipkorir, E, Raes, D \& Rao, M 2008, 'Analysis of rainfall onset, cessation and length of growing season for western Kenya', Agricultural and Forest Meteorology, vol. 148, no. 6-7, pp. 1123-1135.

NeFo (Netzwerk-Forum zur Biodiversitätsforschung Deutschland) 2010, Ökosystemdienstleistungen von Wäldern. viewed 4 October 2012,

$<$ http://www.biodiversity.de./images/stories/themen/Oekosystemdienstleistungen/2_wlder_12-042011.pdf>.

Nthuni, SM 2010, Spatial modelling of rainwater harvesting potential for the Kakamega area in western Kenya, Unpublished Master's Thesis, Faculty of Geomatics, Karlsruhe University of Applied Sciences, Germany.

Oduor, AR \& Gadain, HM 2007, Potential of rainwater harvesting in Somalia: A planning, design, implementation and monitoring framework, Technical Report No.W-09, FAO-SWALIM, Nairobi, Kenya, $<$ http://www.faoswalim.org/downloads/Pages\%20from\%20W09\%20Potential\%20of\%20Rain\%20Water\%20Harvesting\%20in\%20Somalia.pdf>.

Roebuck, RM 2007, A whole life costing approach for rainwater harvesting systems: An investigation into the whole life cost implications of using rainwater harvesting systems for non-potable applications in new-build developments in the United Kingdom, $\mathrm{PhD}$ Thesis, University of Bradford, United Kingdom.

Rosen, S \& Vincent, JR 1999, Household water resources and rural productivity in Sub-Saharan Africa: A review of the evidence, Harvard Institute for International Development, Cambridge (USA), viewed 19 May 2010, <http://www.cid.harvard.edu/archive/events/cidneudc/papers/rosenvincent.pdf>.

Schaab, G, Lübker, T, Lung, T \& Nthuni, SM 2011, 'Applications of object-based image analysis results for the farmland surrounding Kakamega Forest in western Kenya', 34th International Symposium on Remote Sensing of Environment “The GEOSS Era: Towards Operational Environmental Monitoring”, Sydney (Australia), 10-15 April 2011. 
Schaab, G \& Lung, T 2010, 'Subproject E02: GIS and remote sensing in support of biodiversity management at the landscape scale for rainforests in eastern Africa'. In W Freund \& JW Wägele (eds.), Biodiversity in Conversion - Conservation and Sustainable Use of East African Rain Forest Ecosystems, BIOTA East Africa - Final Report Phase III (2007-2010), pp. 27-53.

Sekar, I \& Randhir, TO 2007, 'Spatial assessment of conjunctive water harvesting potential in watershed systems', Hydrology, vol. 334, pp. 39-52.

Sheil, D 2014, 'How plants water our planet: advances and imperatives', Trends in Plant Science, vol. 19, no. 4 , pp. 209-211.

Susilawati, CL \& Tunggul, S 2011, 'Model development of rainwater management for agriculture decision support system in semi-arid area', Civil Engineering Dimension, vol. 13, no. 2, pp. 107-112.

TWDB (Texas Water Development Board) 2005, The Texas manual on rainwater harvesting, 3rd edition, Texas Water Development Board, Austin (USA), viewed 25 November 2013, <http://www.ecy.wa.gov/programs/wr/hq/pdf/texas_rw_harvestmanual_3rdedition.pdf $>$.

UNDP (United Nations Development Programme) 2006, Human development report 2006: Beyond scarcity: Power, poverty and the global water crisis. United Nations Development Programme, New York, viewed 15 June 2010, <http://hdr.undp.org/en/media/HDR06-complete.pdf>.

Vishwanath, S 2001, 'Domestic rainwater harvesting. Some applications in Bagalore, India', Rain Water Harvesting, New Delhi (India), 18-20 April 2001.

Weerasinghe, H, Schneider, UA \& Löw, A 2010, 'Water harvest- and storage- location optimization model using GIS and remote sensing', BALWOIS 2010 Conference on Water Observation and Information System for Decision Support, Ohrid (Macedonia), 25-29 May 2010.

WRC (World Resources Institute) 2007, Nature's benefits in Kenya. An atlas of ecosystems and human wellbeing, Washington, Nairobi.

\section{Acknowledgements}

We acknowledge funding by BMBF (German Federal Ministry of Education and Research) under BIOTA Africa (Biodiversity Monitoring Transect Analysis in Africa; sub-project E02, 01LC0625D1) and highly appreciated the scholarship provided by KAAD (Catholic Academic Exchange Service). We also appreciated the valuable comments of the reviewers and thank Donald Friend (MNSU) for correcting the English. 